\title{
Evaluation of the nutritive value of muiumba (Baikiaea plurijuga) seeds: chemical composition, in vitro organic matter digestibility and in vitro gas production
}

\author{
Miguel A M Rodrigues ${ }^{1 *}$, Ana L Lourenço ${ }^{1}$, John W Cone ${ }^{3}$, Fernando M Nunes², Ana S Santos ${ }^{4}$, \\ José M M Cordeiro ${ }^{5}$, Cristina M V Guedes ${ }^{1}$ and Luis M M Ferreira ${ }^{1}$
}

\begin{abstract}
One of the main constraints hindering the increase of animal production in semi-arid regions of Africa is the inadequate supply of nutrients during the dry season. Incorporation of alternative feed resources in ruminant diets during this period could be a viable approach to overcome these limitations. The objective of this study was to evaluate the nutritive value of muiumba (Baikiaea plurijuga) tree seeds as an alternative nutrient source for ruminants. Muiumba seeds were compared to other eight feedstuffs including two cereal grains (corn and oat), two wheat by-products (wheat bran and distilled wheat) and four protein meals (coconut meal, sunflower meal, soybean meal and rapeseed meal) as to its chemical composition, in vitro organic matter digestibility (IVOMD) and in vitro gas production. The moderate crude protein concentrations (145 g/ $\mathrm{kg} \mathrm{DM}$ ) of muiumba seeds indicate that this feedstuff could not be used as a protein supplement, contrarily to the majority of multipurpose tree seeds. Although the starch content was scarce $(15 \mathrm{~g} / \mathrm{kg} \mathrm{DM})$, the low neutral detergent fibre ( $235 \mathrm{~g} / \mathrm{kg} \mathrm{DM})$, low molecular weight sugar $(76.1 \mathrm{~g} / \mathrm{kg} \mathrm{DM})$ and non-starch polysaccharide $(510.5 \mathrm{~g} / \mathrm{kg} \mathrm{DM})$ contents indicate that this feedstuff has potential feeding value. This was confirmed by the IVOMD $(0.770)$ and by the data provided by the in vitro gas production showing that muiumba seeds had high $(P<0.05)$ maximum gas production and fractional fermentation rates, suggesting that these seeds are characterized by a highly fermentable fraction.
\end{abstract}

Keywords: Muiumba seeds; Nutritive value

\section{Introduction}

The nutritive value and production cycle of natural pastures depend on prevailing climate and soil conditions. Ruminant production in semiarid regions, especially small ruminants, is mainly extensive and highly dependent on rangeland resources including crop residues and their byproducts (Ben Salem and Smith 2008). These feeds are characterized by high levels of fibre and low levels of energy, protein, minerals and vitamins, promoting low levels of voluntary intake and digestibility, which leads to an intake below the animal's requirements during long periods

\footnotetext{
* Correspondence: mrodrigu@utad.pt

'Department of Animal Science, Animal Science and Veterinary Research Centre, Universidade de Trás-os-Montes e Alto Douro, P.O. Box 1013, 5001-801 Vila Real, Portugal

Full list of author information is available at the end of the article
}

of the year (Sarwatt et al. 2002). In fact, nutritional deficiencies are accepted to be one of the major technical limitations to increase productivity of ruminant livestock in the tropics (Camero et al. 2001). Several alternatives have been proposed to overcome feed limitations in such extensive production systems. Among these, shrubs and fodder trees (leaves and seeds) are considered to have high potential value as source of essential nutrients. This is due to their high nutritive value, in terms of protein and mineral content, but also to its tolerance to a wide range of management practices, high longevity and capacity to produce fodder when other species become dormant to avoid adverse climatic conditions (Paterson et al. 1998; Camero et al. 2001; Sarwatt et al. 2002; Ben Salem et al. 2004).

Although many studies have been conducted to evaluate the nutritive value of multipurpose trees and shrub 
legumes, results from tree seeds are scarce on literature. The existing studies show that these seeds can be an interesting nutrient source (Salawu et al. 1999; Smith et al. 2005; Mlambo et al. 2008). Native trees such as muiumba (Baikiaea plurijuga) are important sources of browse for ruminant production within the areas of Miombo woodlands of Africa, namely in the Cunene region. Small ruminants produced in this region exhibit, in particular during the dry season (from May to August), a natural tendency to ingest the young leaves and seeds of Baikiaea plurijuga as a complement to their limited availability and low nutritive herbaceous diet. In spite of this well-known behaviour, the nutritive value of these seeds cannot be found in the literature. The objective of this study was to evaluate the nutritive value of muiumba seeds and to compare it with conventional ruminant feedstuffs to verify its potential as an alternative feed in ruminant extensive production systems.

\section{Materials and methods Feedstuffs}

Nine feedstuffs were evaluated in this study. Two cereal grains (corn and oat), two wheat by-products (wheat bran and distilled wheat), four protein meals (coconut meal, sunflower meal, soybean meal and rapeseed meal) and muiumba seeds were analysed. Feeds were chosen in order to cover a wide range in chemical composition and in vitro digestibility. Mature muiumba seeds were collected in the semiarid region of the Cunene basin (Angola) during the dry season. Samples were dried in a forced-air oven (Venticell, Munchen, Germany) at $60^{\circ} \mathrm{C}$ for $24 \mathrm{~h}$ for dry matter (DM) determination. Dried samples were ground to pass $1 \mathrm{~mm}$ screen (Retsch, Cutting mill, model SM1, Haan, Germany) and stored in airtight flasks at room temperature for subsequent laboratorial analysis. For starch and non-starch polysaccharides (NSP) analysis, samples were ground to pass a $0.5 \mathrm{~mm}$ screen (Cyclotec, Tecator, Hoganas Sweden).

\section{Chemical analysis}

Samples were analysed in quadruplicate using the procedures described by AOAC, Association of Official Analytical Chemists (1990) for ash (\#942.05), crude protein (\#954.01) and ether extract (\#920.39). Neutral detergent fibre (NDF) was determined by the detergent procedures of Van Soest et al. (1991). Sodium sulphite was not added and heat stable amylase (Sigma A3306, St. Louis, Ill, USA) was only added to cereal grains and wheat by-products samples. Klason lignin (KL) was determined using a two stage sulphuric acid hydrolysis according to the method proposed by Theander and Westerlund (1986).

Low molecular weight sugars (LMW) were analysed according to the methods of Knudsen (1997) with minor modifications. Samples of approximately $500 \mathrm{mg}$ were weighed into $50 \mathrm{~mL}$ centrifuge tubes. Fifteen $\mathrm{mL}$ of an ethanol solution $(500 \mathrm{~mL} / \mathrm{L})$, including $2 \mathrm{~mL}$ of an internal standard (arabinose, $1 \mathrm{mg} / \mathrm{mL}$ ), were added and the samples sonicated and extracted in a water bath for $60 \mathrm{~min}$ at $65^{\circ} \mathrm{C}$. During extraction the tubes were mixed (vortex mixer) three times and finally centrifuged ( $2200 \mathrm{~g}$, $20 \mathrm{~min}$ ). An aliquot of $1 \mathrm{~mL}$ was removed from the supernatant and diluted with $5 \mathrm{~mL}$ of water and analysed by anion-exchange chromatography with pulsed amperometric detection (HPAEC-PAD). The HPAEC system used consisted of the model ICS-5000 (Thermo Fisher Scientific Inc., Dionex, USA) equipped with an ED40 electrochemical detector (Thermo Fisher Scientific Inc., Dionex, USA) with a working gold electrode. Low molecular weight sugars were analysed by isocratic elution with $0.05 \mathrm{M} \mathrm{NaOH}$ containing $0.002 \mathrm{M}$ of $\mathrm{Ba}(\mathrm{OH})_{2}$ at $0.5 \mathrm{~mL} / \mathrm{min}$ with a CarboPac PA-20 column (Thermo Fisher Scientific Inc., Dionex, USA). Sugar composition from the total and insoluble non-starch polysaccharides (NSP) were analysed by isocratic elution with $0.018 \mathrm{M}$ $\mathrm{NaOH}$ containing $0.002 \mathrm{M}$ of $\mathrm{Ba}(\mathrm{OH})_{2}$ at $1 \mathrm{~mL} / \mathrm{min}$ with a CarboPac PA-1 column (Thermo Fisher Scientific Inc., Dionex, USA). The injection volume was $10 \mu \mathrm{L}$, and the column and detector temperature was set at $25^{\circ} \mathrm{C}$. All individual sugar values were converted to their equivalent polysaccharide value using appropriate conversion factors; 0.88 for pentoses and deoxyhexoses and 0.9 for other hexoses.

The starch content was determined according to the enzymatic method proposed by Salomonsson et al. (1984), with amyloglucosidase from Aspergillus niger (Sigma, A3042; $6000 \mathrm{U} / \mathrm{ml}$ ) and heat stable amylase (Sigma A3306, Ill) using a spectrometer (U2000, Hitachi Ltd., Japan).

Total, soluble, and insoluble NSP were determined using the Knudsen (1997) procedures with minor modifications. Briefly, samples were weighed into $50 \mathrm{~mL}$ centrifuge tubes. Acetate-buffer with $\mathrm{CaCl}_{2}(0.1 \mathrm{M} ; 0.02 \mathrm{M} ; \mathrm{pH} 5.0 ; 9.8 \mathrm{ml})$, termostable $\alpha$-amylase (Termamyl, Novo Nordisk A/S.; $100 \mu \mathrm{L}$ ) was added and the samples were incubated for $1 \mathrm{~h}$ at $100^{\circ} \mathrm{C}$. Complete degradation of starch was achieved after $2 \mathrm{~h}$ with $\beta$-glucanase free amyloglucosidase from Aspergillus niger (Boehringer Mannheim $\mathrm{GmbH}$, Cat No. $1202367: 135 \mathrm{U} / \mathrm{ml} ; 100 \mu \mathrm{L})$ at $60^{\circ} \mathrm{C}$. Soluble NSP were precipitated with 4 volumes of an ethanol solution $(990 \mathrm{~mL} / \mathrm{L})$ for $1 \mathrm{~h}$ on ice bath, the tubes centrifuged (4600 rpm; $10 \mathrm{~min}$ ) and the supernatant discarded. Residues were washed twice with an ethanol solution $(850 \mathrm{~mL} / \mathrm{L})$ and once with acetone and dried in a hood overnight. Polysaccharides in starch free residues were treated with $12 \mathrm{M} \mathrm{H}_{2} \mathrm{SO}_{4}\left(35^{\circ} \mathrm{C} 60 \mathrm{~min}\right)$ and hydrolysed to monosaccharides with $1 \mathrm{M}\left(100^{\circ} \mathrm{C} .120 \mathrm{~min}\right)$. An internal standard (2-deoxyglucose $1 \mathrm{mg} / \mathrm{mL} ; 500 \mu \mathrm{L}$ ) was added to the hydrolysate aliquot. Neutral sugar analysis was 
performed by HPAEC-PAD (section 2.2.1.). The uronic acids were measured spectrophotometrically with Dgalacturonic acid solutions as standards according to the method described by Scott (1979).

The soluble NSP in the starch-free residue were extracted by a phosphate buffer (Englyst et al. 1982) at neutral $\mathrm{pH}\left(0.2 \mathrm{M} ; 100^{\circ} \mathrm{C} ; 60 \mathrm{~min} ; \mathrm{pH} 7.0\right)$ and the neutral and acidic sugars in the insoluble NSP were analysed as described for total NSP.

\section{Incubation procedures}

Two cows, weighing $500 \pm 36 \mathrm{~kg}$ live weight and fitted with permanent ruminal cannulae (Bar Diamond Inc., Parma ID, USA), were used to collect rumen fluid. Cows were housed in individual stalls in a ventilated barn. The diet consisted of meadow hay and commercial concentrate making 75:25 ratio on a DM basis and was offered at 1.2 times the maintenance requirements (Thomas, 2004). Animals were fed in equal portions at 0800 and $1600 \mathrm{~h}$ and had free access to water and mineral-vitamin blocks. The concentrate was offered to the animals prior to the hay. Rumen fluid samples were drawn $2 \mathrm{~h}$ after the morning feed into pre-warmed insulated flasks previously filled with $\mathrm{CO}_{2}$. Rumen fluid was strained through 4 layers of cheesecloth and kept at $39^{\circ} \mathrm{C}$ under $\mathrm{CO}_{2}$.

In vitro organic matter digestibility (IVOMD) was determined according to Tilley and Terry (1963) modified by Marten and Barnes (1980). Each sample was incubated in quadruplicate in one series. Fermentations were in $50 \mathrm{~mL}$ centrifuge tubes containing $250 \mathrm{mg}$ of sample and $25 \mathrm{ml}$ of buffered rumen fluid solution. Immediately after addition of buffer solution, flasks were closed with rubber stoppers fitted to a Bunsen valve. After $48 \mathrm{~h}$ of incubation a pepsin/ $\mathrm{HCl}$ solution was added and the incubation was prolonged by $24 \mathrm{~h}$.

Rumen fluid used to measure in vitro gas production was mixed $(1: 2 \mathrm{v} / \mathrm{v})$ with an anaerobic buffer/mineral solution (Cone et al. 1996). All laboratory handling was under continuous flushing with $\mathrm{CO}_{2}$. Samples $(500 \mathrm{mg}$ ) were accurately weighed into $250 \mathrm{~mL}$ serum bottles (Schott, Mainz, Germany) and incubated in $60 \mathrm{ml}$ buffered rumen fluid. Each sample was incubated in two series, completed on different days. Gas production was recorded every $20 \mathrm{~min}$ for $72 \mathrm{~h}$ using a fully automated system (Cone et al. 1996).

\section{Calculations and statistical analysis}

Gas curves were fitted by iteration to a mono-phasic model as described by Groot et al. (1996) as:

$$
Y=A /\left(1+(B / t)^{C}\right)
$$

where: $A=$ estimated asymptotic gas production; $B=$ time of incubation at which half of the asymptotic gas production has been formed; $C=$ sharpness of the switching characteristic for the profile.

Maximum rate of gas production $\left(R_{\max } G\right)$ and the time at which maximum rate of gas production is reached $\left(T R_{\max } G\right)$ were calculated according to Yang et al. (2005) as:

$$
\begin{aligned}
R_{\max } G= & A\left(B^{C}\right) C\left(T R_{\max } G^{(-C-1)}\right) / \\
& \left(1+\left(B^{C}\right)\left(T R_{\max } G^{(-C)}\right)\right)^{2}
\end{aligned}
$$

and

$$
T R_{\max } G=B((C-1) /(C+1))^{1 / C}
$$

Fractional rate of substrate fermentation $(R)$ was calculated using the equation of Groot et al. (1996) as:

$$
R=\left(C T R_{\max } G^{(C-1)}\right) /\left(B^{C}+T R_{\max } G^{C}\right)
$$

All data were expressed in terms of $\mathrm{ml}$ of gas/g OM fermented.

In vitro organic matter digestibility and in vitro gas production parameters were analysed according to a completely randomized design using GLM of SAS (SAS, 2004). Differences between treatment means were determined using Tukey's test with a predetermined significance level of $P<0.05$.

\section{Results}

The chemical composition of the feeds is presented in Table 1. Muiumba seeds were characterized by low levels of protein $(145 \mathrm{~g} / \mathrm{kg} \mathrm{DM})$ compared to protein concentrates normally used in ruminant feeding namely rapeseed and soybean meals. Its NDF content was rather low (235 g/kg DM) compared to the majority of the other feeds, with the exception of corn and soybean meal. Nevertheless, lignin content was quite high $(180 \mathrm{~g} / \mathrm{kg}$ DM) ranking above all the other feeds. Muiumba seeds also presented low starch concentrations (15 g/ $\mathrm{kg} \mathrm{DM})$.

As to the composition in LMW sugars (Table 2) muiumba seeds ranked $(76.1 \mathrm{~g} / \mathrm{kg} \mathrm{DM})$ along the feeds presenting medium concentrations. The relative proportion of the individual LMW sugars varied among feeds. Muiumba seeds mainly contain maltose, raffinose and sucrose being the raffinose content particularly high $(25.0 \mathrm{~g} / \mathrm{kg}$ DM) compared to the other feedstuffs.

The composition of the NSP fraction is presented in Table 3 and differed greatly between feeds. Muiumba seeds, wheat bran, coconut and sunflower meals presented much higher NSP concentrations (around $500 \mathrm{~g} / \mathrm{kg} \mathrm{DM}$ ) than cereal grains, distilled wheat, rapeseed and soybean meal. Muiumba seeds were characterized by an insoluble fraction that was twice the soluble one, glucose being the main component of NSP in muiumba seeds (59\% of total 


\begin{tabular}{|c|c|c|c|c|c|c|}
\hline Feeds & Ash & $\mathrm{CP}$ & NDF & $\mathrm{KL}$ & $\mathrm{EE}$ & Starch \\
\hline Muiumba seeds & $26 \pm 0.3$ & $145 \pm 3.2$ & $235 \pm 7.9$ & $180 \pm 10.5$ & $101 \pm 4.7$ & $15 \pm 1.2$ \\
\hline Corn & $15 \pm 0.7$ & $87 \pm 3.1$ & $100 \pm 8.3$ & $34 \pm 3.8$ & $46 \pm 5.6$ & $789 \pm 20.4$ \\
\hline Oats & $25 \pm 0.7$ & $100 \pm 4.2$ & $315 \pm 7.7$ & $104 \pm 9.8$ & $51 \pm 4.9$ & $464 \pm 35.5$ \\
\hline Distilled wheat & $83 \pm 1.3$ & $329 \pm 7.4$ & $453 \pm 12.9$ & $87 \pm 6.9$ & $47 \pm 5.1$ & $25 \pm 2.7$ \\
\hline Wheat bran & $94 \pm 1.8$ & $113 \pm 1.6$ & $547 \pm 7.6$ & $148 \pm 9.9$ & $41 \pm 4.3$ & $154 \pm 14.3$ \\
\hline Coconut meal & $71 \pm 1.6$ & $213 \pm 7.2$ & $555 \pm 10.2$ & $66 \pm 4.4$ & $56 \pm 2.0$ & $25 \pm 2.6$ \\
\hline Sunflower meal & $65 \pm 0.3$ & $257 \pm 4.4$ & $485 \pm 8.8$ & $129 \pm 7.9$ & $24 \pm 3.0$ & $15 \pm 0.7$ \\
\hline Rapeseed meal & $73 \pm 0.3$ & $353 \pm 5.6$ & $325 \pm 11.3$ & $139 \pm 4.4$ & $38 \pm 1.5$ & $25 \pm 1.3$ \\
\hline Soybean meal & $70 \pm 0.9$ & $444 \pm 8.7$ & $147 \pm 3.1$ & $36 \pm 4.1$ & $19 \pm 2.1$ & $27 \pm 0.7$ \\
\hline
\end{tabular}

$C P$ crude protein, NDF neutral detergent fibre, $K L$ Klason lignin, $E E$ ether extract.

NSP) - distributed in equal absolute amounts in soluble and insoluble fraction - and followed by xylose (19\% of total NSP) and galactose (17\% of total NSP).

The IVOMD differed $(P<0.001)$ between feeds (Table 4$)$, being that of muiumba seeds relatively high (0.770). Gas production profiles showed variations $(P<0.001)$ in both rate and extent of fermentation among feedstuffs (Table 4$)$. The estimated asymptotic gas production of muiumba seeds showed an intermediate value $(257.6 \mathrm{ml} / \mathrm{g} \mathrm{OM}$, $P<0.05)$ which was similar to the values found for oats, distilled wheat and coconut, rapeseed and soybean meal. The maximum rate of gas production $(\operatorname{Rmax} G)$ and the fractional rate of fermentation $(R)$ showed highest values $(P<0.05)$ for oats, muiumba seeds and corn $(23.8,24.9$, and $26.7 \mathrm{~mL} / \mathrm{h}$, and $0.107,0.130$ and $0.100 / \mathrm{h}$, respectively).

\section{Discussion}

The chemical composition of muiumba seeds showed that this feedstuff could only supply moderate concentrations of protein making unviable its utilization as a protein supplement. Generally, it is assumed that a feed above $200 \mathrm{~g} / \mathrm{kg}$ DM crude protein and less than $180 \mathrm{~g} / \mathrm{kg}$ DM crude fibre (Harris et al. 1968, 1980) could be considered a protein supplement. The low protein value for muiumba may come as a surprise since it is a legume tree and thus a higher protein value was expected. In fact, although tree seeds can be used as protein sources, even for humans (Adewusi et al. 2003), CP values reported herein are lower than those reported for seeds from other types of fodder trees. Data concerning seeds from different species of Acacia trees show an average $\mathrm{CP}$ content around $300 \mathrm{~g} / \mathrm{kg}$ DM (Mahala and Elseed 2007). Other multipurpose trees with a wide agricultural use in Africa, including human consumption and animal feed, are Moringa species. Results presented by Melesse et al. (2009) for seeds of Moringa stenopetala show higher CP values, around $400 \mathrm{~g} / \mathrm{kg} \mathrm{DM}$. Generalizations maybe somewhat misleading as chemical composition is subjected to wide fluctuations depending on soil and climate characteristics. A recent study from Soliva et al. (2008) confirms the importance of multipurpose tree seeds as protein sources, showing that fruits and seeds medium CP concentration of ten different plants was around $300 \mathrm{~g} / \mathrm{kg} \mathrm{DM}$.

Table 2 Low molecular weight sugars of feedstuffs (g/kg DM) compared in the present study, results are expressed as mean \pm SE

\begin{tabular}{|c|c|c|c|c|c|c|c|}
\hline Feeds & Glucose & Frutose & Sucrose & Maltose & Verbascose & Raffinose & Total \\
\hline Muiumba seeds & $0.18 \pm 0.01$ & $4.24 \pm 0.12$ & $13.83 \pm 0.55$ & $32.88 \pm 1.97$ & ND & $25.00 \pm 1.41$ & 76.1 \\
\hline Corn & $1.49 \pm 0.05$ & $1.77 \pm 0.05$ & $18.05 \pm 0.41$ & $17.62 \pm 0.77$ & ND & $1.82 \pm 0.09$ & 40.8 \\
\hline Oats & $0.52 \pm 0.03$ & $0.76 \pm 0.02$ & $8.03 \pm 0.25$ & $7.55 \pm 1.97$ & $0.50 \pm 0.02$ & $8.46 \pm 0.51$ & 28.8 \\
\hline Distilled wheat & $0.51 \pm 0.02$ & ND & $6.07 \pm 0.36$ & $1.04 \pm 0.39$ & $0.19 \pm 0.01$ & $1.19 \pm 0.07$ & 9.3 \\
\hline Wheat bran & $2.48 \pm 0.10$ & $1.61 \pm 0.06$ & $20.60 \pm 1.23$ & $49.60 \pm 3.27$ & $0.67 \pm 0.04$ & $12.04 \pm 0.47$ & 87.0 \\
\hline Coconut meal & $0.43 \pm 0.02$ & $5.30 \pm 0.11$ & $52.66 \pm 2.64$ & $3.66 \pm 0.07$ & ND & $5.06 \pm 0.27$ & 67.1 \\
\hline Sunflower meal & $2.96 \pm 0.11$ & $5.09 \pm 0.13$ & $39.60 \pm 2.08$ & $203.30 \pm 10.9$ & $1.16 \pm 0.07$ & $0.78 \pm 0.03$ & 252.6 \\
\hline Rapeseed meal & $0.78 \pm 0.04$ & $1.26 \pm 0.04$ & $58.59 \pm 3.52$ & $1.00 \pm 0.04$ & $0.99 \pm 0.03$ & $1.78 \pm 0.10$ & 62.7 \\
\hline Soybean meal & $0.11 \pm 0.01$ & $0.23 \pm 0.01$ & $39.75 \pm 1.65$ & $115.10 \pm 6.46$ & $28.90 \pm 1.77$ & ND & 184.2 \\
\hline
\end{tabular}

$N D$ not detected. 
Table 3 Composition of non-starch polysaccharides (NSP) of feedstuffs (g/kg DM) compared in the present study, results are expressed as mean \pm SE

\begin{tabular}{|c|c|c|c|c|c|c|c|c|c|}
\hline NSP & $\begin{array}{l}\text { Muiumba } \\
\text { seeds }\end{array}$ & Corn & Oats & $\begin{array}{c}\text { Distilled } \\
\text { wheat }\end{array}$ & $\begin{array}{c}\text { Wheat } \\
\text { bran }\end{array}$ & $\begin{array}{c}\text { Coconut } \\
\text { meal }\end{array}$ & $\begin{array}{c}\text { Sunflower } \\
\text { meal }\end{array}$ & $\begin{array}{c}\text { Rapeseed } \\
\text { meal }\end{array}$ & $\begin{array}{c}\text { Soybean } \\
\text { meal }\end{array}$ \\
\hline \multicolumn{10}{|l|}{ Soluble NSP } \\
\hline Fucose & $0.2 \pm 0.1$ & ND & ND & ND & ND & ND & ND & ND & ND \\
\hline Arabinose & $1.7 \pm 0.2$ & $0.6 \pm 0.1$ & $2.8 \pm 0.2$ & $25.5 \pm 1.8$ & $1.2 \pm 0.1$ & $0.2 \pm 0.1$ & $16.2 \pm 1.3$ & $14.5 \pm 0.9$ & $27.6 \pm 2.3$ \\
\hline Rhamnose & ND & ND & ND & ND & ND & ND & ND & ND & ND \\
\hline Galactose & $14.3 \pm 1.1$ & $0.2 \pm 0.1$ & $0.5 \pm 0.1$ & $1.0 \pm 1.0$ & $0.7 \pm 0.1$ & $1.1 \pm 0.1$ & $3.9 \pm 0.4$ & $0.4 \pm 0.1$ & $50.4 \pm 4.0$ \\
\hline Glucose & $145.1 \pm 12.9$ & $30.2 \pm 2.1$ & $18.4 \pm 1.2$ & $54.5 \pm 4.8$ & $162.1 \pm 14.8$ & $10.1 \pm 0.5$ & $183.3 \pm 10.9$ & $22.8 \pm 2.0$ & $97.3 \pm 8.7$ \\
\hline Xylose & $19.4 \pm 2.4$ & $30.3 \pm 2.7$ & $43.4 \pm 3.9$ & $27.2 \pm 1.8$ & $34.8 \pm 2.5$ & $2.4 \pm 0.2$ & $45.1 \pm 3.1$ & $5.6 \pm 0.5$ & $8.8 \pm 0.8$ \\
\hline Mannose & ND & $11.5 \pm 0.6$ & $2.0 \pm 0.2$ & $0.3 \pm 0.1$ & $0.8 \pm 0.1$ & $113.1 \pm 9.6$ & $2.7 \pm 0.3$ & $0.8 \pm 0.1$ & $5.9 \pm 0.6$ \\
\hline Uronic acids & $1.7 \pm 0.2$ & $1.0 \pm 0.1$ & $0.1 \pm 0.1$ & $0.4 \pm 0.1$ & $1.5 \pm 0.1$ & $0.5 \pm 0.1$ & $9.2 \pm 0.8$ & $0.9 \pm 0.1$ & $2.3 \pm 0.2$ \\
\hline Total & $182.4 \pm 13.1$ & $73.8 \pm 3.5$ & $67.2 \pm 4.1$ & $108.9 \pm 5.5$ & $201.1 \pm 15.0$ & $127.4 \pm 9.6$ & $260.6 \pm 11.4$ & $45.0 \pm 2.26$ & $192.3 \pm 9.9$ \\
\hline \multicolumn{10}{|l|}{ Insoluble NSP } \\
\hline Fucose & $0.3 \pm 0.1$ & ND & ND & ND & ND & ND & ND & ND & ND \\
\hline Arabinose & $33.3 \pm 3.9$ & $18.0 \pm 1.1$ & $7.6 \pm 0.6$ & $18.0 \pm 1.5$ & $55.0 \pm 4.2$ & $6.6 \pm 0.6$ & $16.9 \pm 1.3$ & $41.3 \pm 0.4$ & $8.0 \pm 0.8$ \\
\hline Rhamnose & ND & ND & ND & ND & ND & ND & ND & ND & ND \\
\hline Galactose & $72.2 \pm 5.4$ & $3.3 \pm 0.2$ & $2.7 \pm 0.2$ & $3.5 \pm 0.3$ & $5.3 \pm 0.4$ & $13.3 \pm 1.2$ & $5.3 \pm 0.4$ & $13.4 \pm 1.0$ & $12.5 \pm 0.9$ \\
\hline Glucose & $150.0 \pm 13.4$ & $30.8 \pm 1.6$ & $66.4 \pm 5.6$ & $61.0 \pm 5.1$ & $217.8 \pm 16.8$ & $54.0 \pm 4.3$ & $135.6 \pm 11.2$ & $98.9 \pm 8.1$ & $25.8 \pm 2.1$ \\
\hline Xylose & $78.6 \pm 4.6$ & $35.2 \pm 2.5$ & $77.7 \pm 6.9$ & $65.5 \pm 5.8$ & $239.3 \pm 16.2$ & $1.9 \pm 0.2$ & $80.8 \pm 7.1$ & $17.1 \pm 1.6$ & $5.8 \pm 0.5$ \\
\hline Mannose & ND & $1.3 \pm 0.1$ & $1.5 \pm 0.1$ & $13.5 \pm 1.1$ & $1.9 \pm 0.2$ & $300.1 \pm 25.2$ & $7.0 \pm 0.6$ & $5.3 \pm 0.5$ & $2.2 \pm 0.2$ \\
\hline Uronic acids & $5.3 \pm 0.6$ & $2.6 \pm 0.3$ & $2.6 \pm 0.2$ & $3.2 \pm 0.3$ & $5.1 \pm 0.4$ & $4.7 \pm 0.4$ & $18.6 \pm 1.7$ & $23.2 \pm 1.9$ & $10.4 \pm 1.0$ \\
\hline Total & $339.7 \pm 15.7$ & $91.2 \pm 3.3$ & $158.5 \pm 8.9$ & $164.7 \pm 8.0$ & $524.4 \pm 23.6$ & $380.6 \pm 25.6$ & $264.1 \pm 13.5$ & $199.2 \pm 8.6$ & $64.7 \pm 2.7$ \\
\hline Total NSP & $522.1 \pm 20.4$ & $165.0 \pm 4.8$ & $225.7 \pm 9.8$ & $273.6 \pm 9.7$ & $725.5 \pm 27.9$ & $508.0 \pm 27.3$ & $524.7 \pm 17.7$ & $244.2 \pm 8.8$ & $257.0 \pm 10.3$ \\
\hline
\end{tabular}

$N D$ not detected.

Table 4 Parameters of gas production profiles fitted with mono-phasic Groot's model and in vitro digestibility of feedstuffs compared in the present study

\begin{tabular}{|c|c|c|c|c|c|c|c|}
\hline \multirow{2}{*}{ Feeds } & \multicolumn{6}{|c|}{ Gas production parameters ${ }^{a}$} & \multirow{2}{*}{ IVOMD' } \\
\hline & $A(\mathrm{ml} / \mathrm{g} O M)$ & $B(h)$ & $C$ & $\operatorname{RmaxG}(\mathrm{ml} / \mathrm{h})$ & $T R \max G(h)$ & $R(/ h)$ & \\
\hline Muiumba seeds & $257.6^{\mathrm{bc}}$ & $6.8^{\mathrm{a}}$ & $2.07^{c}$ & $24.9^{\mathrm{ef}}$ & $4.1^{c d}$ & $0.130^{\mathrm{e}}$ & $0.770^{d}$ \\
\hline Corn & $356.6^{d}$ & $8.8^{\mathrm{cd}}$ & $2.03^{c}$ & $26.7^{f}$ & $5.1^{d}$ & $0.100^{d}$ & $0.851^{\mathrm{g}}$ \\
\hline Oats & $271.2^{\mathrm{bc}}$ & $6.9^{\mathrm{ab}}$ & $1.55^{\mathrm{b}}$ & $23.8^{\mathrm{e}}$ & $2.6^{\mathrm{ab}}$ & $0.107^{d}$ & $0.709^{c}$ \\
\hline Distilled wheat & $262.6^{\mathrm{bc}}$ & $9.9^{\text {de }}$ & $1.36^{\mathrm{ab}}$ & $16.7^{\mathrm{bc}}$ & $2.5^{\mathrm{ab}}$ & $0.074^{b}$ & $0.873^{h}$ \\
\hline Wheat bran & $200.4^{a}$ & $13.0^{f}$ & $1.21^{\mathrm{a}}$ & $10.4^{\mathrm{a}}$ & $1.8^{\mathrm{a}}$ & $0.057^{\mathrm{a}}$ & $0.575^{\mathrm{a}}$ \\
\hline Coconut meal & $287.6^{c}$ & $12.5^{f}$ & $1.93^{c}$ & $14.8^{\mathrm{b}}$ & $6.9^{e}$ & $0.068^{b}$ & $0.807^{e}$ \\
\hline Sunflower meal & $195.6^{\mathrm{a}}$ & $6.9^{\mathrm{ab}}$ & $1.48^{\mathrm{b}}$ & $17.2^{\mathrm{cd}}$ & $2.3^{\mathrm{ab}}$ & $0.105^{d}$ & $0.678^{\mathrm{b}}$ \\
\hline Rapeseed meal & $256.7^{b}$ & $8.1^{b c}$ & $1.48^{\mathrm{b}}$ & $19.4^{d}$ & $2.7^{\mathrm{ab}}$ & $0.090^{c}$ & $0.825^{f}$ \\
\hline Soybean meal & $282.0^{b c}$ & $10.4^{e}$ & $1.48^{b}$ & $16.6^{\mathrm{bc}}$ & $3.4^{b c}$ & $0.070^{b}$ & $0.968^{i}$ \\
\hline SEM & 9.62 & 0.39 & 0.073 & 0.70 & 0.39 & 0.003 & 0.005 \\
\hline Probability & $<0.001$ & $<0.001$ & $<0.001$ & $<0.001$ & $<0.001$ & $<0.001$ & $<0.001$ \\
\hline
\end{tabular}

Means in rows with different letters differ at $P<0.05$.

${ }^{\text {a }} A$ is the estimated asymptotic gas production; $B$ is the time of incubation at which half of the asymptotic gas production has been formed; $C$ is the sharpness of the switching characteristic for the profile; $R \max G$ is the maximum rate of gas production; TRmax $G$ is the time at which maximum rate of gas production is reached; $R$ is the fractional rate of fermentation.

${ }^{\mathrm{b}}$ In vitro organic matter digestibility. 
Although its starch content is practically inexistent, the reduced NDF concentration together with the relatively high content in LMW sugars and NSP indicate that muiumba seeds could have potential feeding value as a dietary component for ruminants in areas where one of the most important factors limiting productivity is limited feed supply. The high glucose content as well as the xylose and galactose concentration of NSP (Table 3) suggests that muiumba seeds are rich in glucans, xyloglucans and galactans. This is not surprising since legume seeds are usually rich in these compounds (Buckeridge et al. 1995; 2000; Srivastava and Kapoor 2005). Although xyloglucan, one of the most abundant hemicelluloses, can generally be found in the plant cell wall structure it can also be a storage polysaccharide in some tree seeds. Like starch, galactan-containing polysaccharides are also considered to be storage carbohydrates and thus easily fermentable by the rumen microbial population. Furthermore, as lignin concentration is very similar to the NDF content, the majority of the fibrous fraction of the muiumba seeds is basically lignin and a small amount of cellulose. These concentrations mainly derive from the hulk, which in these seeds is firmly coated making its removal quite complicated. In this way, it could be argued that the fibrous content of muiumba seeds would not affect the digestibility of other compounds. This is confirmed by the values of IVOMD presented in Table 4. In fact, assuming that the NDF content of muiumba seeds $(235 \mathrm{~g} / \mathrm{kg} \mathrm{DM})$, mainly present in the hulk, is totally indigestible then the remaining fraction is practically totally digestible, as the IVOMD of muiumba averaged 0.770 . This feature would rank muiumba seeds along the feedstuffs (Table 4) with higher digestibility in case the hulk could be removed.

Data for most of the seeds from other types of fodder trees also show that one of the main constraints on its utilization as animal feed is the inhibitory effect of lignin, limiting intake and digestibility of nutrients, as well

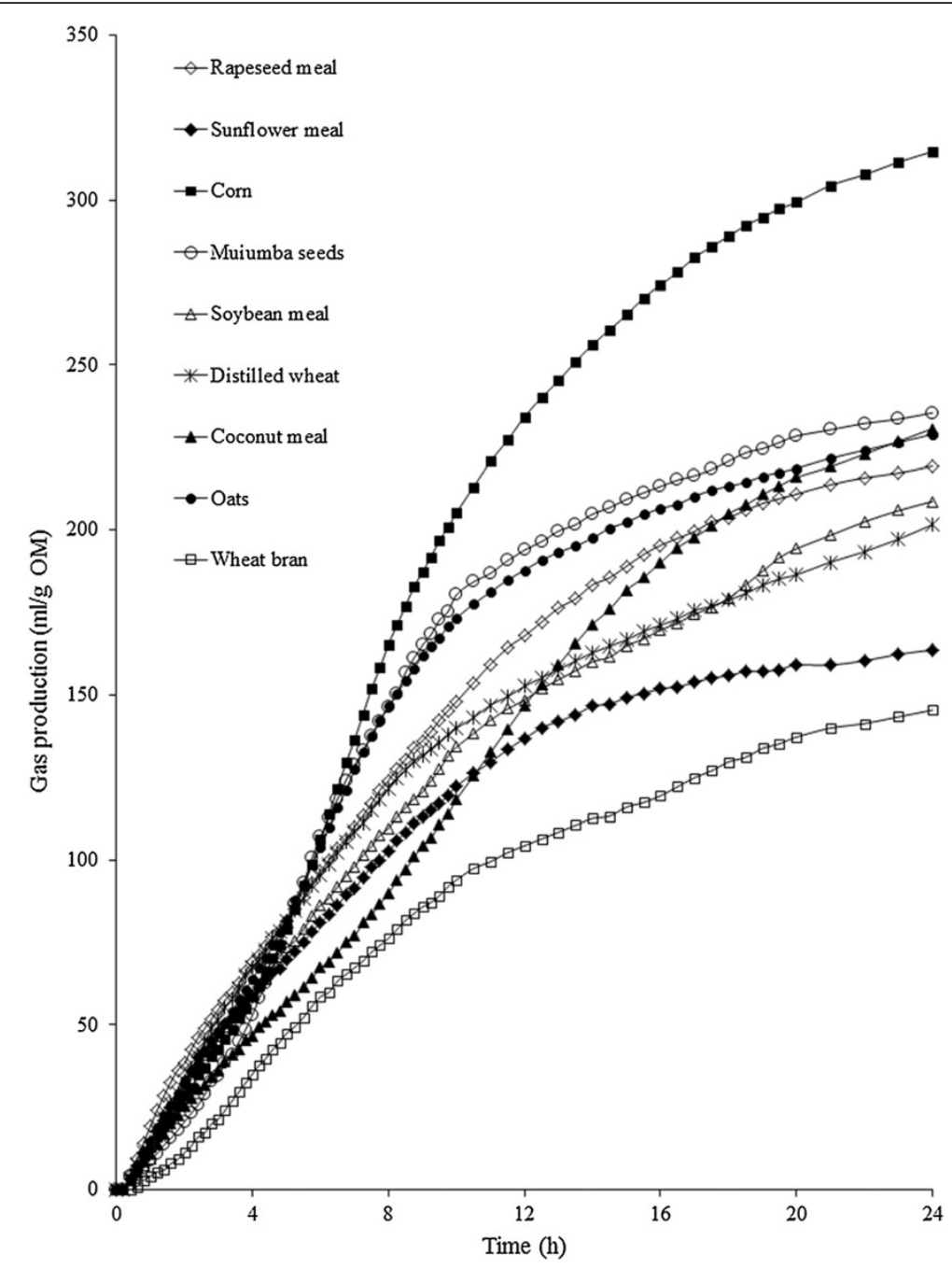

Figure 1 Gas production curves of feedstuffs compared in the present study. 
as the concentrations of other anti-nutritional compounds. As previously discussed, this is not the case for muiumba seeds. Additionally, although values reported in the literature are quite variable within fodder tree species, muiumba seeds presented higher IVOMD when compared to the results reported by Melesse et al. (2009) for organic matter digestibility of Moringa stenopetala (523 $\mathrm{g} / \mathrm{kg} \mathrm{OM})$ and Salawu et al. (1999) for in vitro DM degradation of Calliandra calothyrsus (471 $\mathrm{g} / \mathrm{kg} \mathrm{DM}$ ) seeds. Data presented by Aganga and Mosase (2001) also point out to low dry matter digestibility values for the seeds of indigenous trees species of southern Africa, with a value around $400 \mathrm{~g} / \mathrm{kg}$ DM. Tree seeds from the reported species generally present quite variable digestibility values. This feature is expected since it depends on its chemical composition. The phenolic content of fodder trees and shrubs is usually considered as one of the main factors that negatively affects its digestibility, and several authors have reported this fact (; Smith et al. 2005; Ben Salem and Smith 2008; Blache et al. 2008). A large number of non-conventional feedstuffs, such as tree seeds, may contain secondary compounds that are potentially toxic, due to their structure and rate of intake (Blache et al. 2008). Whether muiumba is rich on phenolic compounds will have to be evaluated in future trials. Nevertheless, the IVOMD value found in our study indicates that whatever the concentration of phenolic compounds in muiumba seeds its nutritive value is high.

The in vitro gas production data are in agreement with the IVOMD results, and confirm the muiumba seeds potential as an animal feed. The estimated asymptotic gas production $(A)$ ranked it as similar to other commonly used supplements. Furthermore, its maximum gas production rate (RmaxG) and its fractional fermentation rate $(\mathrm{R})$ showed that muiumba seeds are characterized by a highly fermentable fraction. By applying the equation suggested by Menke and Steingass (1988), for metabolizable energy calculations, Muimba seeds presented values of $9.1 \mathrm{MJ} / \mathrm{kg} \mathrm{DM}$. This feature mainly reflects the close association between the chemical composition on low molecular weight sugars and non-starch polysaccharides and fermentation rates, meaning that both soluble and the majority of non-soluble components have high rumen fermentability. The description of gas production profiles can be attributed to the fermentation of several fractions (Cone et al. 1997); a sub-curve outlining the water-soluble fraction, another outlining the non-soluble fraction and an additional one describing the microbial turnover. In a study comparing 20 feed samples Van Gelder et al. (2005) verified that gas production of the soluble and insoluble fractions could be estimated from the gas produced by each substrate at $3 \mathrm{~h}$ and $20 \mathrm{~h}$ incubation, respectively. These data support the findings of Cone et al. (1997) that for different types of substrate also pointed out that the gas production sub- curves could be estimated using this approach. In this way, sugars and the majority of proteins are considered to ferment within the first 3 hours of fermentation while starch and NSP are fermented between 3 and 20 hours of fermentation, depending on the substrates chemical composition. In fact, fibrous feedstuffs will tend to show lower fermentation rates and the period of fermentation of the non-soluble fraction will be more extensive due to the higher concentration of cell wall components. The gas production observed for the different feedstuffs used in this study (Figure 1) indicate that after $5 \mathrm{~h}$ of fermentation muiumba seeds gas production had a significant contribution of the non-soluble fraction, confirming that the NSP fraction is highly fermentable.

\section{Conclusions}

This is the first study presenting data on the nutritional value of muiumba seeds. Our results suggest that although muiumba seeds have a moderate concentration of crude protein and vestigial starch contents, its high digestibility and fermentation patterns suggest that its carbohydrate fraction is easily fermented. Nevertheless, further studies should be performed in order to evaluate the presence of anti-nutritional constituents such as tannins and other phenolic compounds.

\section{Abbreviations \\ A: Estimated asymptotic gas production; B: Time of incubation at which half of the asymptotic gas production (A) has been formed; C: Sharpness of the switching characteristic for the gas production profile; CP: Crude protein; DM: Dry matter; EE: Ether extract; IVOMD: In vitro OM digestibility; KL: Klason lignin; LMW: Low molecular weight; NDF: Neutral detergent fibre; OM: Organic matter; NSP: Non-starch polysaccharides; R: Fractional rate of substrate fermentation; RmaxG: Maximum rate of gas production; TRmaxG: Time at which maximum rate of gas production is reached.}

\section{Competing interests}

The current study had no kind of conflict of interest. All authors confirm the above statement.

Authors state that animals used to obtain the rumen fluid were kept during the experimental trial in accordance with the Portuguese law (Portaria $\mathrm{n}^{\circ}$ 1005/92) on animal care in experimental research.

All authors have given consent to their inclusion in this study.

\section{Authors' contributions}

MAMR contributed to the chemical analyses, carried out the in vitro incubations, and drafted the manuscript. ALL contributed to the chemical and statistical analyses. JWC contributed to the in vitro incubations. FMN carried out the NSP analyses. ASS to the in vitro incubations. JMMC was responsible for the collection of samples and contributed to the chemical analyses. CMVG contributed to the chemical and statistical analyses. LMMF contributed to the manuscript draft. All authors read and approved the final manuscript.

\section{Acknowledgments}

The authors wish to acknowledge the financial support from FCT, project PEst-OE/AGR/UI0772/2011.

\section{Author details}

${ }^{1}$ Department of Animal Science, Animal Science and Veterinary Research Centre, Universidade de Trás-os-Montes e Alto Douro, P.O. Box 1013, 5001-801 Vila Real, Portugal. ²Department of Chemistry, Chemistry Research Centre, Universidade de Trás-os-Montes e Alto Douro, Vila-Real, Portugal. 
${ }^{3}$ Wageningen Institute of Animal Sciences, Animal Nutrition Group, Wageningen University, Wageningen, The Netherlands. ${ }^{4}$ Department of Veterinary Medicine, Animal Science and Veterinary Research Centre, Universidade Vasco da Gama, Coimbra, Portugal. ${ }^{5}$ Department of Animal Production, Faculty of Veterinary Medicine, Universidade José Eduardo dos Santos, Huambo, Angola.

Received: 27 February 2014 Accepted: 11 June 2014 Published: 25 June 2014

\section{References}

Adewusi SRA, Falade OS, Harwood C (2003) Chemical composition of Acacia colei and Acacia tumida seeds-potential food sources in the semi-arid tropics. Food Chem 80:187-195

Aganga AA, Mosase KW (2001) Tannin content, nutritive value and dry matter digestibility of Lonchocarpus capassa, Zizyphus mucronata, Sclerocarya birrea, Kirkia acuminate and Rhus lancea seeds. Anim Feed Sci Technol 91:107-113

AOAC, Association of Official Analytical Chemists (1990) Official Methods of Analysis, 16th edn. AOAC, Arlington, VA, USA

Ben Salem H, Smith T (2008) Feeding strategies to increase small ruminant production in dry environments. Small Ruminant Res 77:174-194

Ben Salem H, Makkar HPS, Nefzaoui A (2004) Towards better utilisation of non-conventional feed sources by sheep and goats in some African and Asian countries. In: Ben Salem H, Nefzaoui A, Morand-Fehr P (eds) Nutrition and feeding strategies of sheep and goats under harsh climates. CIHEAM-IAMZ. Options Méditerranéennes: Série A. Séminaires Méditerranéens, vol 59. pp 177-187

Blache D, Maloney SK, Revell KD (2008) Use and limitations of alternative feed resources to sustain and improve reproductive performance in sheep and goats. Anim Feed Sci Technol 147:140-157

Buckeridge MS, Panegassi VR, Rocha DC, Dietrich SMC (1995) Seed Galactomannan in the classification and evolution of the Leguminosae. Phytochemistry 38:871-875

Buckeridge MS, Santos HP, Tiné MAS (2000) Mobilisation of storage cell wall polysaccharides in seeds. Plant Physiol Biochem 38:141-156

Camero A, Ibrahim M, Kass M (2001) Improving rumen fermentation and milk production with legume-tree fodder in the tropics. Agrofor Syst 51:157-166

Cone JW, Van Gelder AH, Visscher GJW, Oudshoorn L (1996) Influence of rumen fluid and substrate concentration on fermentation kinetics measured with a fully automated time related gas production apparatus. Anim Feed Sci Technol 61:113-128

Cone JW, Van Gelder AH, Driehuis F (1997) Description of gas production profiles with a three phasic model. Anim Feed Sci Technol 66:31-45

Englyst HN, Wiggins HS, Cummings JH (1982) Determination of non-starch polysaccharides in plant foods by gas-liquid chromatography of constituent sugars as alditol acetates. Analyst 107:307-318

Groot JC, Cone JW, Williams BA, Debersaques FMA, Latinga EA (1996) Multiphasic analysis of gas production kinetics for in vitro fermentation of ruminant feeds. Anim Feed Sci Technol 64:77-89

Harris LE, Asplund JM, Crampton EW (1968) An International Feed Nomenclature and Methods for Summarizing and Using Feed Data to Calculate Diets, Bull, vol No 479. Agricultural Experimental Station, Utah State University, Logan, Utah

Harris LE, Jager F, Leche TF, Mayr H, Neese U, Kearl LC (1980) International Feed Descriptions. International Feed Names and Country Feed Names, INFIC Publ. No 5. International Feedstuffs Institute, Utah State University, Logan, Utah

Knudsen KEB (1997) Carbohydrate and lignin contents of plant materials used in animal feeding. Anim Feed Sci Technol 67:319-338

Mahala AG, Elseed ANF (2007) Chemical composition and in vitro gas production characteristics of six fodder trees leaves and seeds. Res J Agri Biol Sci 3:983-986

Marten GC, Barnes RF (1980) Prediction Of Energy Digestibility Of Forages With In Vitro Rumen Fermentation and Fungal Enzyme Systems. In: Pigden WJ, Balch CC, Graham M (eds) Proceedings of International Workshop on Standardization of Analytical Methodology for Feeds. International Development Research Center, Ottawa, pp 61-71

Melesse A, Bulang M, Kluth $H$ (2009) Evaluating the nutritive values and in vitro degradability characteristics of leaves, seeds and seedpods from M. stenopetala. J Sci Food Agriculture 89:281-287
Menke KH, Steingass H (1988) Estimation of the energetic feed value obtained from chemical analysis and gas production using rumen fluid. Anim Res Dev 28:7-55

Mlambo V, Mould FL, Sikosana JLN, Smith T, Owen E, Mueller-Harvey I (2008) Chemical composition and in vitro fermentation of tannin-rich tree fruits. Anim Feed Sci Technol 140:402-417

Paterson RT, Karanja GM, Roothaert RL, Nyaata OZ, Kariuki IW (1998) A review of tree fodder production and utilization within smallholder agroforestry systems in Kenya. Agrofor Syst 41:181-199

Salawu MB, Acamovic T, Stewart CS, Roothaert RL (1999) Composition and degradability of different fractions of Calliandra leaves, pods and seeds. Anim Feed Sci Technol 77:181-199

Salomonsson AC, Theander O, Westerlund E (1984) Chemical characterization of some Swedish cereal whole meal and bran fractions. Swedish J Agri Res 14:111-117

Sarwatt SV, Kapange SS, Kakengi AMV (2002) Substituting sunflower seed-cake with Moringa oleifera leaves as a supplemental goat feed in Tanzania. Agrofor Syst 56:241-247

SAS (2004) SAS User's Guide. SAS Institute, Inc., Cary, NC, USA

Scott RW (1979) Colorimetric determination of hexuronic acids in plant materials. Anal Chem 51:936-941

Smith T, Mlambo V, Sikosana JLNS, Maphosa V, Mueller-Harvey I, Owen E (2005) Dichrostachys cinerea and Acacia nilotica fruits as dry season feed supplements for goats in a semi-arid environment: summary of a DFID funded project in Zimbabwe. Anim Feed Sci Technol 122:149-157

Soliva CR, Zeleke AB, Clement C, Hess HD, Fievez V, Kreuzer M (2008) In vitro screening of various tropical foliages, seeds, fruits and medicinal plants for low methane and high ammonia generating potentials in the rumen. Anim Feed Sci Technol 147:53-71

Srivastava M, Kapoor VP (2005) Seed galactomannans: an overview. Chem Biodivers 2:295-317

Theander O, Westerlund EA (1986) Studies on dietary fiber. 3. Improved procedures for analysis of dietary fiber. J Agr Food Chem 34:330-336

Thomas C (2004) Feed into Milk: A New Applied Feeding System for Dairy Cows. Nottingham University Press, Nottingham, UK

Tilley JMA, Terry RA (1963) A two stage technique for the in vitro digestion of forage crops. J Br Grassland Soc 18:104-111

Van Gelder AH, Hetta M, Rodrigues MAM, De Boever JL, Den Hartigh H, Rymer C, van Oostrum M, van Kaathoven R, Cone JW (2005) Ranking of in vitro fermentability of 20 feedstuffs with an automated gas production technique: Results of a ring test. Anim Feed Sci Technol 123-124:243-253

Van Soest PJ, Robertson JB, Lewis BA (1991) Methods for dietary fiber, neutral detergent fiber, and nonstarch polysaccharides in relation to animal nutrition. J Dairy Sci 74:3583-3597

Yang HJ, Tamming S, Williams BA, Dijkstra J, Boer H (2005) In vitro gas and volatile fatty acids production profiles of barley and maize and their soluble and washout fractions after feed processing. Anim Feed Sci Technol 120:125-140

doi:10.1186/2193-1801-3-311

Cite this article as: Rodrigues et al: Evaluation of the nutritive value of muiumba (Baikiaea plurijuga) seeds: chemical composition, in vitro organic matter digestibility and in vitro gas production. SpringerPlus 2014 3:311.

\section{Submit your manuscript to a SpringerOpen ${ }^{\odot}$ journal and benefit from:}

- Convenient online submission

$\checkmark$ Rigorous peer review

- Immediate publication on acceptance

- Open access: articles freely available online

- High visibility within the field

- Retaining the copyright to your article

Submit your next manuscript at $>$ springeropen.com 